medRxiv preprint doi: https://doi.org/10.1101/2020.07.21.20157370; this version posted July 26, 2020. The copyright holder for this preprint (which was not certified by peer review) is the author/funder, who has granted medRxiv a license to display the preprint in perpetuity.

It is made available under a CC-BY-NC-ND 4.0 International license .

\title{
Candida (Diutina) mesorugosa in Non-Albicans Candida Species Clinical Isolates in South West
} Nigeria

Oloche Owoicho ${ }^{1,2}$, Judith Uche Oguzie ${ }^{1,2}$, Tosin Segun Ogunbiyi ${ }^{1,2}$, Toyin Adulsalam ${ }^{1,2}$, Philomena Eromon ${ }^{1}$, Onikepe Folarin ${ }^{1,2}$, Ernest Uzodimma Durugbo*2and Christian T. Happi ${ }^{1,2}$

1. African Centre of Excellence for Genomics of Infectious Diseases, Redeemer's University, Ede, Osun State, Nigeria.

2. Department of Biological Sciences, Redeemer's University, Ede, P.M.B. 230, Ede, Osun State, Nigeria.

*Corresponding author: durugboe@run.edu.ng

\section{Abstract \\ Introduction}

The emerging role of non-albicans Candida species (NACS) as causal agents of mild to lifethreatening mycoses is increasingly being appreciated. Some NACS are known for intrinsic resistance or reduced susceptibility to some antifungal drugs. To inform on therapeutic options and management of candidiasis, we embarked on Candida species surveillance in South west Nigeria.

\section{Method}

We obtained retrospective yeast isolates from urogenital samples of patients in a tertiary hospital in South west Nigeria. Among 47 isolates identified phenotypically, we encountered a yeast which failed to produce pseudohyphae in human serum but was morphologically similar to Candida albicans. We characterized this yeast by sequencing the internal transcribed spacer (ITS1-5.8S-ITS2) region of the ribosomal DNA.

\section{Results}


medRxiv preprint doi: https://doi.org/10.1101/2020.07.21.20157370; this version posted July 26, 2020. The copyright holder for this preprint (which was not certified by peer review) is the author/funder, who has granted medRxiv a license to display the preprint in perpetuity. It is made available under a CC-BY-NC-ND 4.0 International license .

A BLAST search and sequence homology identified the yeast as Candida (Diutina) mesorugosa, with a strong bootstrap.

\section{Conclusion}

Candida mesorugosa, a rarely isolated yeast from clinical samples worldwide, should be considered among potentially relevant NACS in Nigerian clinics. To the best our knowledge, this is the first report of Candida mesorugosa from a clinical sample in Nigeria. This finding confirms the need for more specific methods, such as DNA sequencing, for extensive surveillance of NACS. Key words: Candida mesorugosa, Candida rugosa complex, Non-albicans Candida species surveillance, ribosomal DNA sequencing, NACS

\section{Introduction}

Candida (Diutina) mesorugosaCandida (Diutina) rugosa, Candida (Diutina) pseudorugosa and Candida (Diutina) neurorugosa are members of Candida rugosa complex (Paredes et al. 2012). Members of Candida rugosa complex exist predominantly in the environment, and are widely used in the food, cosmetic and pharmaceutical industries for their lipase (Benjamin and Pandey 1998). However, C. rugosa complex are associated with mastitis in dairy cattle (Scaccabarozzi et al. 2011). Episodes of human candidemia caused by C. rugosa complex have also been reported (Pfaller et al. 2010; Singh et al. 2011). Like many non-albicans Candida species (NACS), reduced susceptibility to azoles was observed in the rugosa complex (Pfaller et al. 2010). Taken together, $C$. rugosa complex are considered emerging agents of antifungal refractory infections. 
medRxiv preprint doi: https://doi.org/10.1101/2020.07.21.20157370; this version posted July 26, 2020. The copyright holder for this preprint (which was not certified by peer review) is the author/funder, who has granted medRxiv a license to display the preprint in perpetuity. It is made available under a CC-BY-NC-ND 4.0 International license .

Surveillance of Candida species has been recommended due to increasing threat of NACS and to inform on strategies for prevention and management of recalcitrant mycoses. However, in under-resourced countries, including Nigeria, surveillance is hampered by use of less robust and sensitive techniques. To circumvent this challenge, we collected retrospective yeast isolates recovered from patients, with the aim of speciating the yeasts, using molecular diagnostics, DNA sequencing and Bioinformatics approaches. This short communication is part of the ongoing project.

\section{Materials and Methods}

Forty-seven putative yeast isolates recovered from urogenital samples of patients from February to May 2018 were obtained from Ladoke Akintola University of Technology Teaching Hospital, Osogbo, a tertiary hospital in South west Nigeria. The isolates were sub-cultured on Sabouraud dextrose agar at $37^{\circ} \mathrm{C}$ for 48 hours and initially identified using CHROMagar ${ }^{\mathrm{TM}}$ Candida (ChromAgar, Paris, France). An isolate, here designated NG06, which did not produce pseudohyphae in human serum, but was morphologically similar to C. albicans was selected for molecular identification. The isolate was subjected to heat shock (da Silva et al. 2012) then genomic DNA was extracted using Qiagen DNeasy Blood and Tissue Kit (Qiagen, Germany) following the manufacturer's instructions. ITS1-5.8S-ITS2 region of the rDNA was amplified by PCR using ITS1 (5'-TCC GTA GGT GAA CCT GCGG-3') and ITS4 (5'-TCC TCC GCT TAT TGA TAT GC-3) universal primers (Integrated DNA Technology, USA). The PCR reaction mixture comprised $5 \mu \mathrm{L}$ of DNA template, $0.4 \mu \mathrm{L}$ of each primer and $12.5 \mu \mathrm{L}$ of One Taq Quick Load Master Mix (2X) (New England BioLabs) made up to a final volume of $25 \mu \mathrm{L}$ by PCR grade water. PCR amplification was 
medRxiv preprint doi: https://doi.org/10.1101/2020.07.21.20157370; this version posted July 26, 2020. The copyright holder for this preprint (which was not certified by peer review) is the author/funder, who has granted medRxiv a license to display the preprint in perpetuity. It is made available under a CC-BY-NC-ND 4.0 International license .

performed on Mastercycler Pro-Vapo. project (Eppendorf AG,Hamburg, Germany) using the thermo-cycling conditions described previously (Solimani et al. 2014). The amplicons were subjected to $2 \%$ agarose gel electrophoresis and visualized. The amplicons were sequenced on Applied Biosystems 3500xL Genetic Analyzer (Thermo Fisher Scientific, UK). For bioinformatics analyses, the sequence was imported to Unipro-UGENE, viewed and edited where necessary. Further, the sequence was compared against a non-redundant database (NCBI) to infer homology based on the hits found. A multiple alignment was generated by combining the sequence and the best hits. The best hits were chosen based on bits score, e-value, maximum score and query coverage. Phylogenetic trees were generated from the alignment dataset, producing a Maximum-likelihood tree which was estimated by using Kimura's two-parameter method implemented in Unipro-UGENE version 34.0. The reliability of the phylogenetic tree was assessed by 1000 bootstrap resampling. The sequence was submitted to NCBI (GenBank accession no.

\section{MT548606).}

\section{Results}

The PCR amplification yielded nucleic acid product of 390bp (Fig. 1). The BLAST search identified the sequence as $C$. (Diutina) mesorugosa, which clustered with known sequences of Diutina mesorugosa, with strong bootstrap support (Fig.2). 
medRxiv preprint doi: https://doi.org/10.1101/2020.07.21.20157370; this version posted July 26, 2020. The copyright holder for this preprint (which was not certified by peer review) is the author/funder, who has granted medRxiv a license to display the preprint in perpetuity.

It is made available under a CC-BY-NC-ND 4.0 International license .

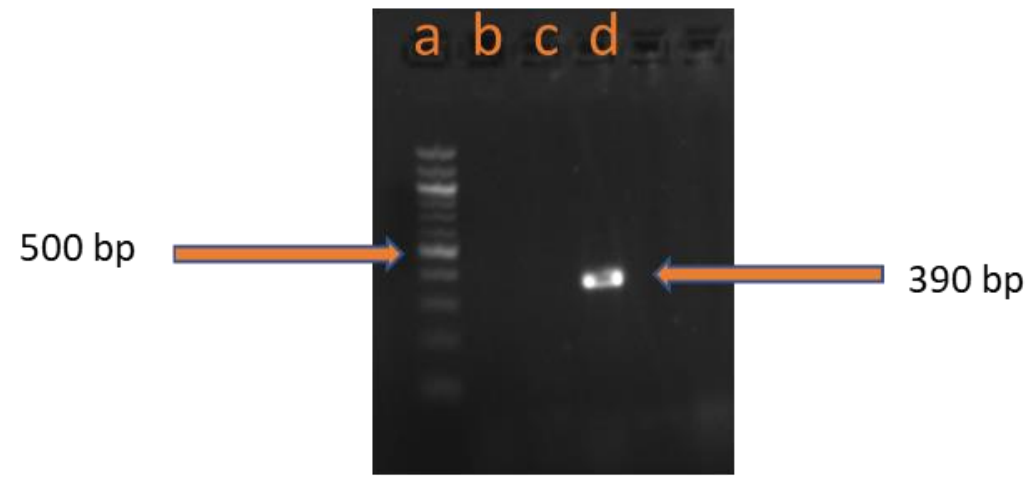

Figure 1. PCR amplification profile of ITS1-5.8S-ITS2 region using ITS1 and ITS4 universal primers. a: 100 bp DNA ladder. d: the amplified fragment for NG06

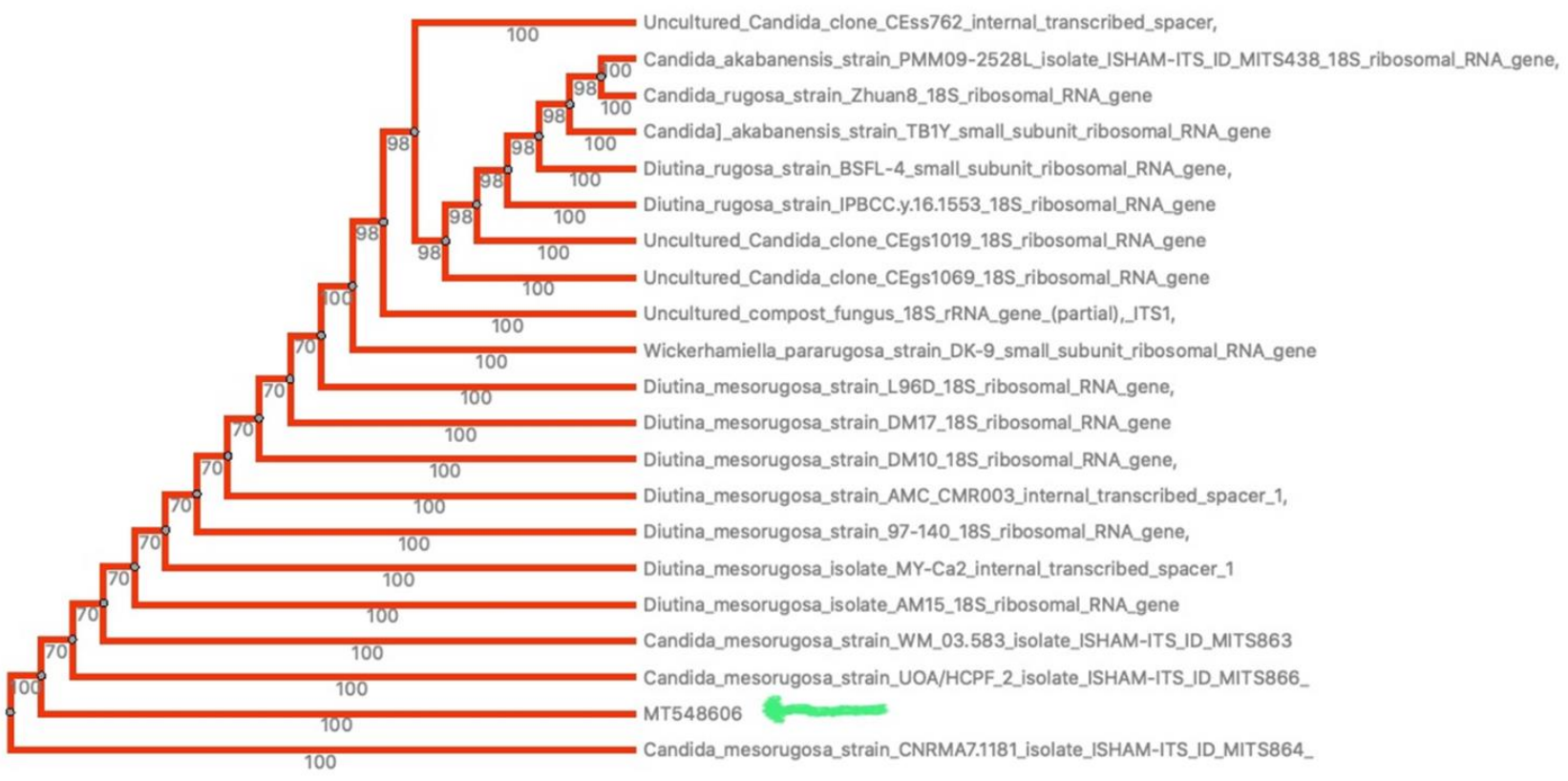

Figure 2. An unrooted phylogenetic tree of the Candida mesorugosa and other Candida species inferred by Maximum-likelihood. The Maximum-likelihood was estimated using Kimura's two parameter method implemented in Unipro-UGENE version 34.0.

\section{Discussion}

Although rugosa complex are relatively common in North India and Latin America, where they account for $18.4 \%$ and $1.2 \%$ of Candida species isolated from patients, respectively, they are 
medRxiv preprint doi: https://doi.org/10.1101/2020.07.21.20157370; this version posted July 26, 2020. The copyright holder for this preprint (which was not certified by peer review) is the author/funder, who has granted medRxiv a license to display the preprint in perpetuity. It is made available under a CC-BY-NC-ND 4.0 International license .

rare in clinical samples worldwide (Pfaller et al. 2010; Singh et al. 2011). In this study, a yeast which was germ tube negative in human serum, but morphologically similar to Candida albicans, was identified as Candida mesorugosa by rDNA targeted sequencing. The $C$. mesorugosa was isolated from a 35-year-old woman who presented with vulvovaginitis after giving birth. The isolate accounts for $2.1 \%$ (1/47) of the Candida species in our study. This value is above the $0.2 \%$ global prevalence of C. rugosa complex previously reported (Pfaller et al. 2010). Possibly, C. rugosa complex are frequent in clinical yeast isolates in Nigeria but are not detected due to over dependence on phenotypic laboratory methods. A high crude mortality rate (33-83\%) is associated with candidemia caused by C. rugosa complex (Minces et al. 2009). Moreover, a recent study identified some virulence features, including C. albicans-comparable biofilm formation, in C. mesorugosa (Montoya et al. 2019). Put together, these call for more surveillance.

\section{Conclusion}

Although the data currently available to us are insufficient to conclude on the causal role of the isolate in the patient's condition, isolation of a rare yeast known to have poor clinical outcome in severely ill patients calls for attention. This study highlights the need for extensive surveillance of NACS in Nigeria, using very specific methods, such as DNA sequencing.

\section{Acknowledgment}

The authors would like to thank the Microbiology Laboratory staff of Ladoke Akintola University of Technology Teaching Hospital, Osogbo for collecting the isolates used in this study. 
medRxiv preprint doi: https://doi.org/10.1101/2020.07.21.20157370; this version posted July 26, 2020. The copyright holder for this preprint (which was not certified by peer review) is the author/funder, who has granted medRxiv a license to display the preprint in perpetuity. It is made available under a CC-BY-NC-ND 4.0 International license.

We would also like to thank Microbiology Laboratory staff of Redeemer's University, Ede, for providing some technical support for this study.

\section{Ethical approval}

This study was approved by the Research Ethics Committee of Ladoke Akintola University of Technology Teaching Hospital, Osogbo (LTH/EC/2018/04/371).

\section{Funding}

This study was supported by grants from the National Institute of Allergy and Infectious Diseases, NIH-H3Africa (U01HG007480 and U54HG007480 to Dr Christian Happi and a grant from the World Bank (project ACE019 to Redeemer's University - Dr Christian Happi).

\section{Author contribution statement}

$\mathrm{OO}$ and EUD conceived the project. OO, PE, OF and EUD designed the study. OO, JUO and TSO performed the experiments. OO and TA analysed the data. OO prepared the first draft of the manuscript. EUD supervised the study. OF and $\mathrm{CH}$ wrote grants applications and secured funding for the study. All authors approved the final version of the manuscript.

\section{Conflict of interest}

The authors declare no conflict of interest

\section{References}

Benjamin S, Pandey A. Candida rugosa lipases: Molecular biology and versatility in 
medRxiv preprint doi: https://doi.org/10.1101/2020.07.21.20157370; this version posted July 26, 2020. The copyright holder for this preprint (which was not certified by peer review) is the author/funder, who has granted medRxiv a license to display the preprint in perpetuity.

biotechnology. Yeast. 1998;14(12):1069-87.

Minces LR, Ho KS, Veldkamp PJ, Clancy CJ. Candida rugosa: a distinctive emerging cause of candidaemia. A case report and review of the literature. Scand J Infect Dis. 2009;41(1112):892-897.

Montoya AM, Luna-Rodríguez CE, Gracia-Robles G, Rojas OC, Treviño-Rangel R de J, González GM. In vitro virulence determinants, comparative pathogenicity of Diutina (Candida) mesorugosa clinical isolates and literature review of the D. rugosa complex. Mycologia [Internet]. 2019;111(3):395-407. Available from: https://doi.org/10.1080/00275514.2019.1585161

Paredes K, Sutton DA, Cano J, Fothergill AW, Lawhon SD, Zhang S, et al. Molecular identification and antifungal susceptibility testing of clinical isolates of the Candida rugosa species complex and proposal of the new species Candida neorugosa. J Clin Microbiol. 2012;50(7):2397-403.

Pfaller MA, Diekema DJ, Gibbs DL, Newell VA, Ellis D, Tullio V, et al. Results from the artemis disk global antifungal surveillance study, 1997 to 2007: A 10.5-year analysis of susceptibilities of candida species to fluconazole and voriconazole as determined by CLSI standardized disk diffusion. J Clin Microbiol. 2010;48(4):1366-77.

Scaccabarozzi L, Locatelli C, Pisoni G, Manarolla G, Casula A, Bronzo V, et al. Short communication: Epidemiology and genotyping of Candida rugosa strains responsible for persistent intramammary infections in dairy cows. J Dairy Sci [Internet]. 2011;94(9):4574- 
medRxiv preprint doi: https://doi.org/10.1101/2020.07.21.20157370; this version posted July 26, 2020. The copyright holder for this preprint

(which was not certified by peer review) is the author/funder, who has granted medRxiv a license to display the preprint in perpetuity.

It is made available under a CC-BY-NC-ND 4.0 International license.

7. Available from: http://dx.doi.org/10.3168/jds.2011-4294

da Silva GA, Bernardi TL, Schaker PDC, Menegotto M, Valente P. Rapid yeast DNA extraction by

boiling and freeze-thawing without using chemical reagents and DNA purification. Brazilian

Arch Biol Technol. 2012;55(2):319-27.

Singh RI, Xess I, Mathur P, Behera B, Gupta B, Misra MC. Epidemiology of candidemia in critically ill trauma patients: Experience of a level I trauma centre in North India. J Med Microbiol. 2011;60(3):342-8.

Solimani P, Salari S, khalizadeh S, Hassanzad M, Khodavaisy S, Abastabar M, et al. Use of PCRRFLP and PCR-HWP1 for identification of Candida species isolated from cystic fibrosis patients. Res Mol Med. 2014;2(3):23-7. 